\title{
Rancang Bangun Penyiraman Otomatis Untuk Tanaman Hias Berbasis Mikrokontroler ESP8266
}

\author{
Zaini Nadizf ${ }^{1}$, Ucuk Darrusalam ${ }^{2}$, Agus Iskandar $^{3}$ \\ ${ }^{1}$ Jurusan Informatika, Fakultas Teknologi Komunikasi dan Informatika, Universitas Nasional \\ ${ }^{2,3}$ Fakultas Teknologi Komunikasi dan Informatika, Universitas Nasional \\ e-mail: ${ }^{1}$ zaini.nadzif29@gmail.com, ${ }^{2}$ ucuk.darrusalam@civitas.unas.ac.id, \\ 3agus.iskandar@civitas.unas.ac.id
}

\begin{abstract}
Abstrak
Tanaman memerlukan air untuk tetap hidup. Salah satunya tanaman hias yang menggunakan media tanah sebagai kehidupannya. Kebutuhan air yang cukup akan membantu tanaman hias dalam membuat makanan pada proses fotosintesis. Air yang disiram ke tanah akan dibawa oleh pembuluh angkut xylem yang ada pada akar untuk dialirkan ke daun. Melalui alat otomatis penyiram tanaman hias berbasis mikrokontroler, akan memudahkan petani dalam mengukur frekuensi air yang tepat untuk kelembaban tanah melalui waktu yang dirancang secara otomatis. Teknik penyiram tanaman secara manual pada lahan yang luas merupakan proses yang kurang efektif dari segi waktu. Oleh karena itu, dirancang sebuah alat otomatis penyiram tanaman untuk mengukur kelembaban tanah menggunakan sensor Soil Moisture dan pengukur waktu oleh RTC DS3231 sebagai inputan saat menggerakkan Motor Servo penyiram otomatis. Sensor Soil Moisture akan mengirim data ke ESP8266 untuk dibaca sebagai data kelembaban tanah oleh thingspeak dan memerintah Motor Servo sebagai pengatur otomatis saat kelembaban tanah sudah cukup maka penyiram otomatis akan menutup saluran air. Hasil dari sensor kelembaban tanah yang di dapat adalah kurang dari 40\% (kering). Beda halnya dengan hasil 60\% (basah). Dan setelah diimplentasikan dan diuji kesistem maka pengujian tersebut sudah sesuai dengan yang diharapkan.
\end{abstract}

Kata kunci-Penyiraman Otomatis, Kelembaban tanah, Tanaman Hias.

Plants need water to stay alive. One of them is ornamental plants that use soil as a medium of life. The need for sufficient water will help ornamental plants in making food in the photosynthesis process. Water that is splashed into the soil will be carried by the xylem transport vessels in the roots to flow to the leaves. Through an automatic sprinkler of ornamental plants based on a microcontroller, it will be easier for farmers to measure the right water frequency for soil moisture through a time that is designed automatically. The technique of watering plants manually on a large area is a process that is less effective in terms of time. Therefore, an automatic plant sprinkler was designed to measure soil moisture using a Soil Moisture sensor and a timer by RTC DS3231 as input when driving the Servo Motor of the automatic sprinkler. The Soil Moisture sensor will send data to the ESP8266 to be read as soil moisture data by thingspeak and command the Servo Motor as an automatic regulator when the soil moisture is sufficient, the sprinkler will automatically close the water channel. The result of soil moisture sensors that can be less than $40 \%$ (dry).The difference is with the result of $60 \%$ (wet). And after being amplitudeed and tested kesistem then the test is in accordance with the expected.

Keywords-Automatic Watering, Soil Moisture, Ornamental Plants. 


\section{PENDAHULUAN}

Kebutuhan air saat melakukan fotosintesis sangat berpengaruh pada sinar matahari dan kelembaban tanah yang cukup. Teknik penyiraman tanaman yang masih dilakukan secara manual dengan cara mengamati tanaman untuk melihat kelembaban tanah, merupakan kegiatan yang bisa dilakukan secara otomatis menggunakan alat mikrokontroler. Sehingga kebutuhan tanaman terhadap air untuk melembabkan tanah tidak perlu dilakukan secara manual lagi.

Relevansi pada penelitian sebelumnya oleh M. Fadhil dan kawan-kawan terhadap penyiraman tanaman otomatis menggunakan sensor RTC DS1307 sebagai pengatur waktu dan ATmega16 sebagai mikrokontroler. Penyiram tanaman dilakukan dengan cara disemprotkan larutan nutrisi dalam bentuk kabut ke akar yang menggantung. Proses ini masih menghasilkan pertumbuhan tanaman yang kurang sempurna karena beberapa faktor yang mempengaruhi pertumbuhan tanaman [1]. Dan kelembaban tanah yang dilakukan penelitian oleh Erricson dan kawan-kawan mengintruksikan sensor YL-69 untuk ditampilkan ke androiud sebagai nilai kelembaban [2]. Penelitian yang sama juga dilakukan oleh Puji Ariyanto terhadap pengatur Motor Servo sebagai pengatur waktu saat menggunakan sensor kelembaban tanah [3]. Penelitan yang di lakukan Zul Azhar dan kawan-kawan terhadap penyiraman otomatis pada tanaman jambu madudeli hijau menggunaman mikrokontroler ATmega328 yang bisa di monitoring melalui android dan computer menggunaman koneksi Bluetooth [4]. Penelitian yang dilakukan oleh Nana Marliza dan Zaidan Saifurrohman terhadap penyiraman otomatis berbasis Arduino UNO dan dimonitor tingkat kelembaban tanahnya oleh sensor YL-69 [5]. Penelitian yang dilakukan oleh Armanto dan Arianto Pratama terhadap penyiram tanaman otomatis menggunakan sensor kelembaban tanah berbasis mikrokontroler yaitu Arduino UNO [6]. Penelitian yang dilakukan oleh Gunawan dan Marlina Sari terhadap penyiram tanaman otomatis menggunakan sensor kelembaban tanah menggunakan prosesor ATmega sebagai mikrokontroler dan mengunakan Valvle Solenoid untuk mengatur aliran air [7]. Penelitian yang dilakukan oleh Chintya Khairunisa dan kawan-kawan terhadap sistem pengendalian pemupukan dan penyiraman otomatis berbasis Arduino Mega 2560 dengan menggunakan website sebagai monitoring [8]. Penelitian yang dilakukan oleh Wisnhu Jatmiko dan kawan-kawan terhadap penyiraman otomatis menggunakan NodeMCU sebagai mikrokontroler seta Sensor Soil Moisture sebagai pengukur kelembaban tanah dan panel surya sebagai pemasok energi listrik [9]. Dan penelitian yang dilakukan oleh Rudi Budi Agung dan kawan-kawan terhadap aplikasi penyiraman otomatis menggunakan sensor kelambaban tanah dan mengunakan mikrokontroler yaitu ATMega 328 serta mengunakan LCD untuk memonitoring kerja alat tersebut [10].

Permasalahan yang sering dialami setiap orang adalah mencari waktu yang tepat untuk menyiram tanaman hiasnya. Maka dari itu fungsi utama dari perancangan alat penyiram otomatis pada tanaman hias ini yaitu mempermudah user dalam merawat tanaman untuk membantu proses pertumbuhan tanaman. Frekuensi air yang menyerap pada tanah diatur oleh Soil Moisture sebagai pengukur tingkat kelembaban tanah. Jika tanah sudah sesuai pada tingkat kelembaban yang diatur maka pemutar waktu otomatis pada mikrokontroler akan segera menutup aliran air.

Berdasarkan hasil dari relevansi yang didapat oleh penelitian di atas terkait penyiraman otomatis maka penelitian ini menggunakan mikrokontroler yang tersambung oleh Wifi untuk mengirim data ke thingspeak sebagai pemantau tanaman hias berdasarkan kelembaban tanah yang dilakukan oleh sensor Soil Moisture. Lalu Motor Servo bertindak sebagai penggerak on dan off saluran air saat nilai kelembaban tanah sudah cukup. Serta thingspeak ini dapat diakses dengan menggunakan berbagai gawai seperti leptop, smartphone, ataupun komputer. 


\section{METODE PENELITIAN}

Perancangan penyiram tanaman otomatis untuk tanaman hias ini melalui proses studi literatur pada kebutuhan sistem dan lainnya sebagai tolak ukur keberhasilan dalam penelitian berbasis mikrokontroler ini[8]. Penelitian dilakukan di tempat tinggal penulis dan dilakukan dalam beberapa hari yang lalu dengan metode yang digunakan yaitu metode rancang bangun.

\subsection{Analisis Kebutuhan Sistem}

Perangkat kebutuhan yang digunakan saat pembangunan sistem merupakan langkah awal dalam mengendalikan suatu kesalahan dini. Perangkat tersebut terdapat pada Tabel 1 [5].

Tabel 1. Kebutuhan Peranngkat

\begin{tabular}{ll}
\hline Perangkat Keras & \multicolumn{1}{c}{$\begin{array}{c}\text { Perangkat } \\
\text { Lunak }\end{array}$} \\
\hline Motor Servo & Arduino IDE \\
ESP8266 & Windows 10 \\
Jumper & \\
RTC DS3231 & \\
Power Supply & \\
Sensor Soil & \\
Moisture & \\
\hline
\end{tabular}

Perangkat yang disebutkan pada Tabel 1 digunakan dalam perancangan alat penyiram otomatis pada tanaman hias. Sebelum merancang alat yaitu menentukan tipe dan jenis yang sesuai dengan penelitian sebagai persiapan tahap selanjutnya setelah mengumpulkan informasi melalui studi literatur.

\subsection{Perancangan Sistem Penyiraman Otomatis}

Pusat pengaturan sistem pada alat penyiram otomatis adalah mikrokontroler ESP8266 yang terintegrasi oleh dua jenis sensor yang digunakan yaitu tipe RTC DS3231 untuk mengatur waktu saat penyiraman dan Soil Moisture sebagai pengukur kelembapan tanah. Lalu sebagai penggerak saluran penyiram tanaman adalah Motor Servo. Konfigurasi sistem yang terhubung pada sistem penyeram otomatis yaitu terdapat di Gambar 1.

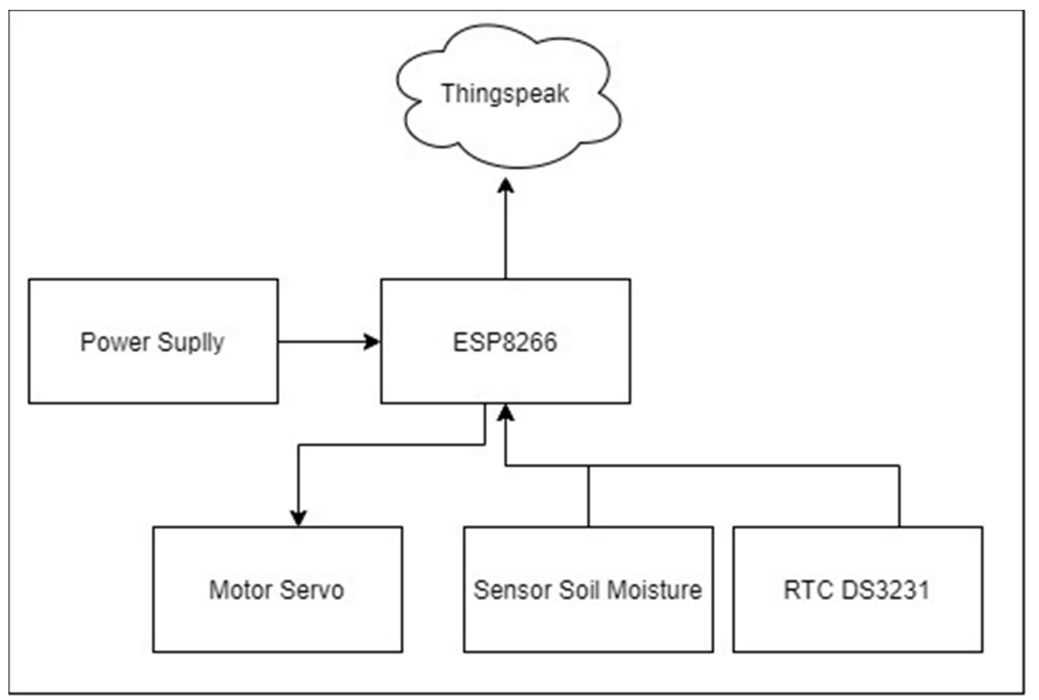

Gambar 1. Diagram Sistem

Nadizf, et., al [Rancang Bangun Penyiraman Otomatis Untuk Tanaman Hias Berbasis Mikrokontroler ESP8266] 
Diagram sistem penyiram otomatis dibentuk melalui alat-alat yang disusun berdasarkan konfigurasinya. Akhir dari sistem yang sudah selesai dirancang, selanjutnya akan dibaca oleh diagram alir dari cara kerja sistem. Diagram alir dibuat untuk mempermudah pengguna dalam menggunakan alat otomatis penyiram tanaman yang digambarkan pada Gambar 2.

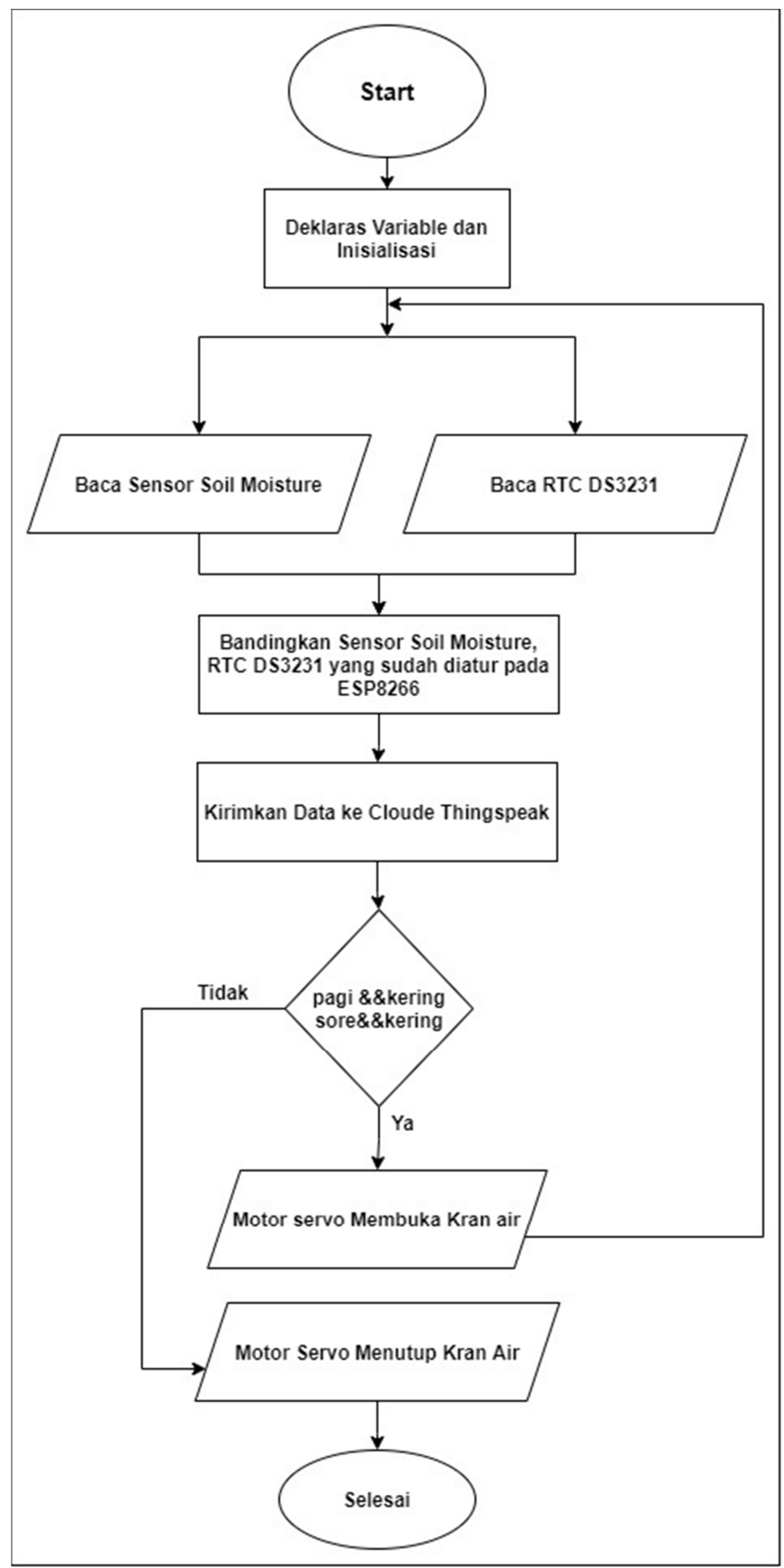

Gambar 2. Flowchart

Dimulai dari deklarasi variable untuk diidentifkasi oleh kedua sensor . Lalu data yang diambil akan diatur oleh ESP8266 untuk dikirim melalui cloud server Thingspeak sebagai penampung data. Data yang ditampung akan diolah untuk dibaca oleh Motor Servo sebagai pembuka dan penutup kran air.

Nadizf, et., al [Rancang Bangun Penyiraman Otomatis Untuk Tanaman Hias Berbasis Mikrokontroler ESP8266] 


\subsection{ESP8266}

ESP8266 digunakan pada sistem irigasi sebagai pusat kontrol yang terhubung dengan sifat SoC (System on Chip) pada modul WiFi. Saat data dikirim melalui sensor kelembaban tanah maka ESP8266 harus terintegrasi dengan cloud server Thingspeak sebagai pemantau data dan penampung data[7].

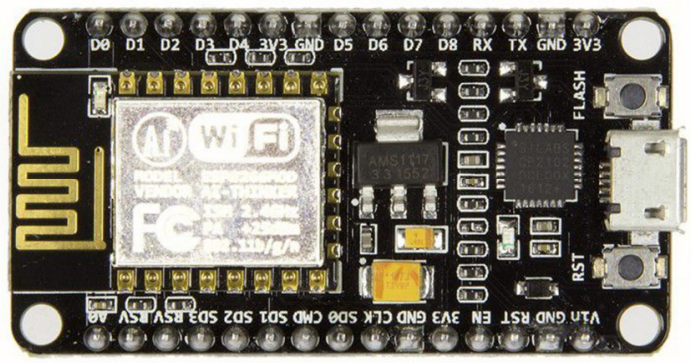

Gambar 3. ESP8266

\subsection{RTC DS3231}

Tipe RTC DS3231 digunakan sebagai akses data pada waktu dan kalender. Tipe ini merupakan pengganti dari DS1302 dan DS1307. Akses data yang dapat ditampung oleh RTC DS3231 yaitu berupa informasi data waktu yang dimuai dari detik hingga tanggal ke tahun. [11].

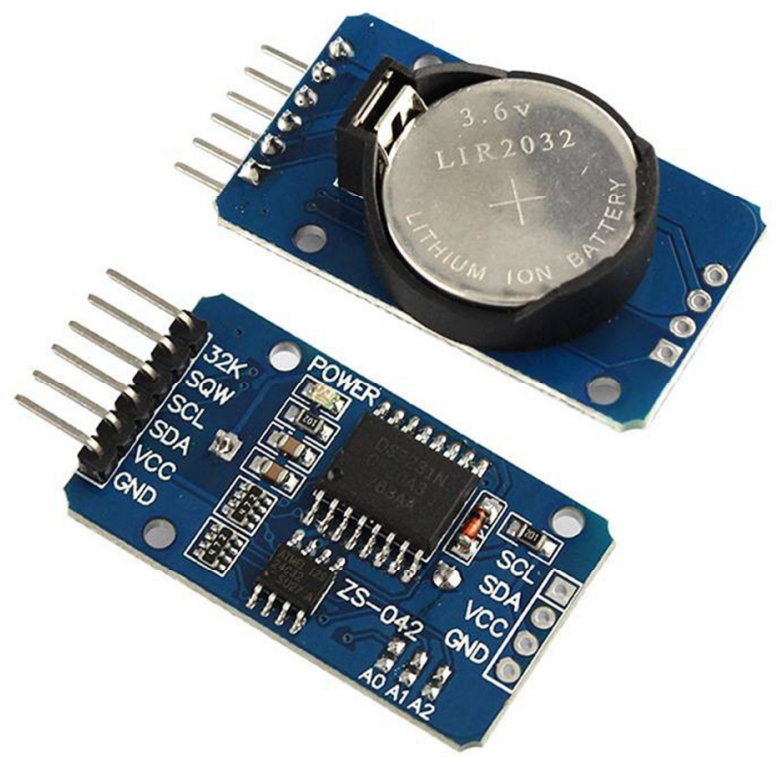

Gambar 4. RTC DS3231

\subsection{Sensor Soil Moisture}

Sensor Soil Moisture merupakan modul yang digunakan sebagai pendeteksi kelembaban tanah untuk diakses oleh mikrokontroler. Sensor ini sering dimanfaatkan oleh beberapa sistem yang sudah ada, seperti pada pertanian, perkebunan maupun hidroponik dan aeroponik Pada sistem yang dirancang oleh penyiram otomatis tanaman hias, digunakan secara online maupun offline sebagai pemantau kelembaban tanah. Cara kerjanya yaitu sensor akan membaca kondisi tanah untuk memberikan output kepada sistem bahwa frekuensi nilai kelembaban tanah sudah cukup[12]. 


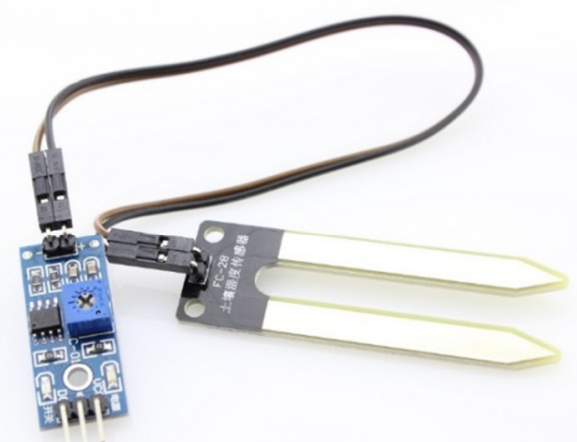

Gambar 5. Sensor Soil Moisture

\subsection{Motor Servo}

Motor Servo merupakan perangkat mesin yang sering digunakan pada industri saat ini sebagai pengubah energi listrik menjadi mekanik dengan kendali akselerasi kecepatan dan keakuratan yang tinggi. Rangkaian yang menggunakan motor servo akan menghasilkan inputan digital maupun analog. Sistem penggerak pada penyiram tanaman otomatis akan menyesuaikan inputan yang berasal dari sensor Soil Moisture.[13].

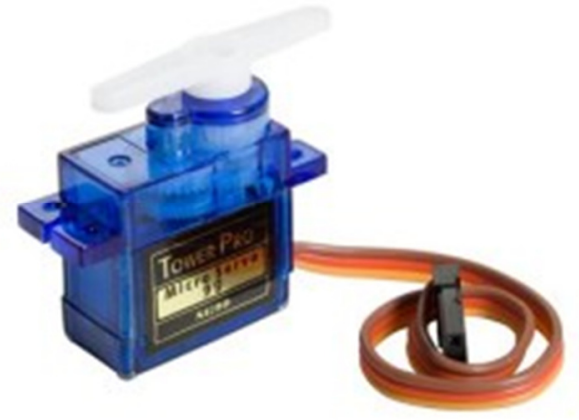

Gambar 6. Motor Servo

\section{HASIL DAN PEMBAHASAN}

Hasil pengumpulan data yang dilakukan untuk mengetahui kelembaban tanah pada tanaman hias adalah akan digunakan sebagai acuan pada perancangan sistem. Sebagai percobaan, lahan yang digunakan yaitu $+30 \mathrm{~cm}$ dengan waktu pengambilan data yaitu pukul 07.00 dan 17.00. Berikut adalah rangkaian komponen mikrokontroler penyiraman tanaman hias sebelu masuk ke hasil pengukuran kelembaban tanah pada tanaman hias. 


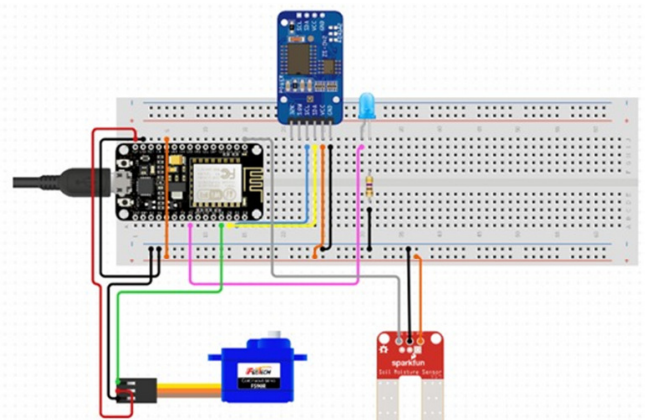

Gambar 7. Komponen Mikrokontroler Penyiram Tanaman Otomatis

Komponen mikrokontroler yang disusun sebagai percobaan telah digambarkan pada Gambar 7. Alat-alat serta tipe yang digunakan menyesuaikan tabel kebutuhan perangkat keras. Rangkaian ini yang akan menghasilkan sistem otomatis pada penyiram tanaman hias yang diatur oleh arduino menggunakan android untuk menjalankan sistem irigasi.

\subsection{Kelembaban Tanah}

Teknik pengumpulan data kelembaban tanah ini ditujuan untuk menghitung data sebagi acuan frekuensi nilai kelembaban yang akan digunakan pada tanaman hias. Variabel kelembaban digunakan oleh skala 0\%-100\% untuk memproses analisa data saat mengkonfersi satuan ke skala persen. Rumus yang digunakan yaitu sebagai berikut:[14].

Kelembaban $=100-\left(\frac{\text { Output Sensor }}{1024} \times 100\right)$

Kelambaban : Nilai Kelembaban

Output Sensor : Nilai Sensor

1024 : Nilai Maksimum Sensor

Tabel 2. Data Kelembaban Tanah

\begin{tabular}{|c|c|c|c|c|c|}
\hline \multicolumn{2}{|c|}{ Hari/Tanggal } & Waktu & Kondisi & $\begin{array}{c}\text { Presentase }(\%) \\
\text { Kelembaban }\end{array}$ & $\begin{array}{l}\text { Status } \\
\text { Tanah }\end{array}$ \\
\hline \multirow{4}{*}{$\begin{array}{l}\text { Senin, } \\
06.2021\end{array}$} & $07-$ & 0650 & Sebelum Disiram & $32 \%$ & Lembab \\
\hline & & 07.10 & Setelah Disiram & $69 \%$ & Basah \\
\hline & & 16.50 & Sebelum Disiram & $39 \%$ & Lembab \\
\hline & & 17.10 & Setelah Disiram & $63 \%$ & Basah \\
\hline \multirow{4}{*}{$\begin{array}{l}\text { Selasa, } \\
2021\end{array}$} & 08-06- & 06.50 & Sebelum Disiram & $39 \%$ & Lembab \\
\hline & & 07.10 & Setelah Disiram & $73 \%$ & Basah \\
\hline & & 16.50 & Sebelum Disiram & $37 \%$ & Lembab \\
\hline & & 17.10 & Setelah Disiram & $66 \%$ & Basah \\
\hline \multirow{4}{*}{$\begin{array}{l}\text { Rabu, } \\
2021\end{array}$} & 09-06- & 06.50 & Sebelum Disiram & $38 \%$ & Lembab \\
\hline & & 07.10 & Setelah Disiram & $68 \%$ & Basah \\
\hline & & 16.50 & Sebelum Disiram & $40 \%$ & Lembab \\
\hline & & 17.10 & Setelah Disiram & $66 \%$ & Basah \\
\hline
\end{tabular}

Berdasarkan data yang dikumpulkan pada Tabel 2 dapat disimpulkan bahwa konfersi kelembaban tanah yang dapat dianjurkan yaitu memliki kisaran 32\%-73\%. Maka diputuskan

Nadizf, et., al [Rancang Bangun Penyiraman Otomatis Untuk Tanaman Hias Berbasis Mikrokontroler ESP8266] 
bahwa presentase dibawah $40 \%$ dikategorikan kedalam kelembaban tanah kering, dan diatas presentase $60 \%$ dikategorikan kedalam kelembaban tanah basah. Sistem ini diatur menggunakan logika pada arduino yang dapat dilihat pada Gambar 8.

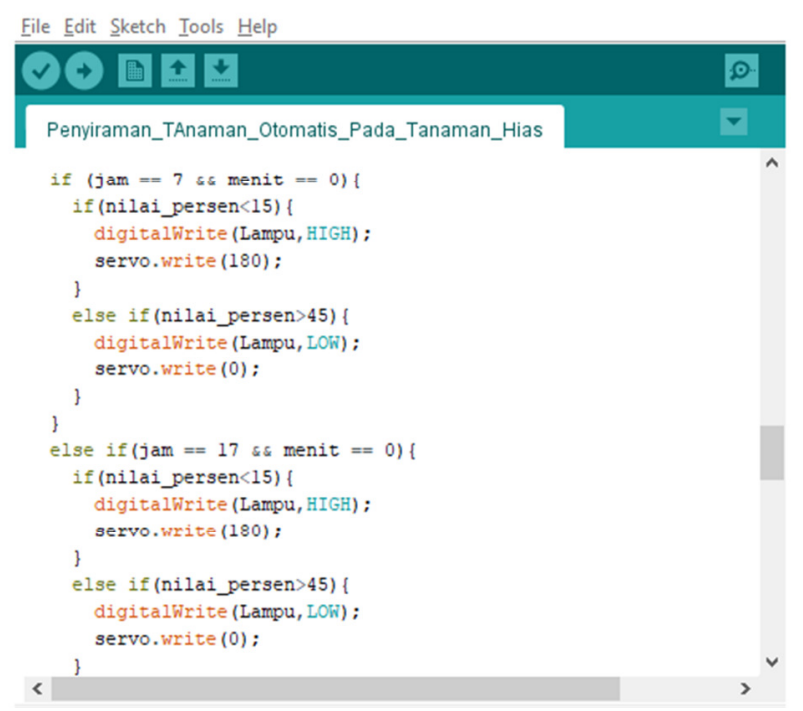

Gambar 8. Source Code Arduino

Penjelasan source code yang diatur pada arduino dapat dibaca dengan hasil kelembaban tanah yang kurang dari $40 \%$ (kering) maka lampu indikator menyala dan motor servo akan bekerja berputar $180^{\circ}$ untuk membuka saluran air. Beda halnya dengan hasil $60 \%$ (basah) maka indikator lampu akan mati sehingga motor servo akan kembali berputar ke sudut $0^{0}$ untuk menutup saluran air.

Dan setelah dikumpulkannya data kelembaban tanah pada tabel 2 akan dilakukan pengujian alat dalam beberapa hari didapatkan data dalam bentuk tabel sebagai berikut. Data yang didapat akan dijelaskan pada tabel 3.

Tabel 3. Data Pengujian Sistem

\begin{tabular}{|c|c|c|c|c|c|}
\hline Tanggal & Waktu & $\begin{array}{c}\text { Data } \\
\text { Kelembaban }\end{array}$ & $\begin{array}{l}\text { Kondisi } \\
\text { Servo }\end{array}$ & Keterangan & Status \\
\hline \multirow[t]{3}{*}{$15-06-2021$} & 06.59 & Kering & OFF & $\begin{array}{l}\text { Kelembaban tanah } 38 \% \\
\text { (kering), servo tetap tertutup } \\
\text { karena belum waktunya } \\
\text { penyiraman }\end{array}$ & Sesua \\
\hline & 07.00 & Kering & $\mathrm{ON}$ & $\begin{array}{l}\text { Kelembaban tanah } 38 \% \\
\text { (kering), servo akan terbuka } \\
\text { karena sudah waktunya } \\
\text { penyiraman }\end{array}$ & Sesuai \\
\hline & 07.01 & Lembab & OFF & $\begin{array}{l}\text { Kelembaban tanah } 67 \% \\
\text { (basah), servo menutup } \\
\text { karena kelembaban sudah } \\
\text { sesuai }\end{array}$ & Sesuai \\
\hline $15-06-2021$ & 16.59 & Kering & OFF & $\begin{array}{l}\text { Kelembaban tanah } 35 \% \\
\text { (kering), servo tetap tertutup } \\
\text { karena belum waktunya } \\
\text { penyiraman }\end{array}$ & Sesuai \\
\hline
\end{tabular}




\begin{tabular}{|c|c|c|c|c|c|}
\hline & 17.00 & Kering & ON & $\begin{array}{l}\text { Kelembaban tanah } 35 \% \\
\text { (kering), servo akan terbuka } \\
\text { karena sudah waktunya }\end{array}$ & Sesuai \\
\hline & 17.01 & Lembab & OFF & $\begin{array}{l}\text { penyiraman } \\
\text { Kelembaban tanah 63\% } \\
\text { (basah), servo menutup } \\
\text { karena kelembaban sudah } \\
\text { sesuai }\end{array}$ & Sesuai \\
\hline \multirow[t]{3}{*}{$16-06-2021$} & 06.59 & Kering & OFF & $\begin{array}{l}\text { Kelembaban tanah } 38 \% \\
\text { (kering), servo tetap tertutup } \\
\text { karena belum waktunya } \\
\text { penyiraman }\end{array}$ & Sesuai \\
\hline & 07.00 & Kering & ON & $\begin{array}{l}\text { Kelembaban tanah } 38 \% \\
\text { (kering), servo akan terbuka } \\
\text { karena sudah waktunya } \\
\text { penyiraman }\end{array}$ & Sesuai \\
\hline & 07.01 & Lembab & OFF & $\begin{array}{l}\text { Kelembaban tanah } 69 \% \\
\text { (basah), servo menutup } \\
\text { karena kelembaban sudah } \\
\text { sesuai }\end{array}$ & Sesuai \\
\hline \multirow[t]{3}{*}{$16-06-2021$} & 16.59 & Lembab & OFF & $\begin{array}{l}\text { Kelembaban tanah } 65 \% \\
\text { (basah), servo tetap tertutup } \\
\text { karena belum waktunya } \\
\text { penyiraman }\end{array}$ & Sesuai \\
\hline & 17.00 & Lembab & OFF & $\begin{array}{l}\text { Kelembaban tanah } 65 \% \\
\text { (basah), servo tetap tertutup } \\
\text { karena hujan dan kelembaban } \\
\text { masih sesuai }\end{array}$ & Sesuai \\
\hline & 17.01 & Lembab & OFF & $\begin{array}{l}\text { Kelembaban tanah } 65 \% \\
\text { (basah), servo tetap tertutup } \\
\text { karena kelembaban masih } \\
\text { sesuai }\end{array}$ & Sesuai \\
\hline \multirow[t]{3}{*}{$17-06-2021$} & 06.59 & Kering & OFF & $\begin{array}{l}\text { Kelembaban tanah } 32 \% \\
\text { (kering), servo tetap tertutup } \\
\text { karena belum waktunya } \\
\text { penyiraman }\end{array}$ & Sesuai \\
\hline & 06.00 & Kering & ON & $\begin{array}{l}\text { Kelembaban tanah } 32 \% \\
\text { (kering), servo akan terbuka } \\
\text { karena sudah waktunya } \\
\text { penyiraman }\end{array}$ & Sesuai \\
\hline & 06.01 & Lembab & OFF & $\begin{array}{l}\text { Kelembaban tanah } 68 \% \\
\text { (basah), servo menutup } \\
\text { karena kelembaban sudah } \\
\text { sesuai }\end{array}$ & Sesuai \\
\hline \multirow[t]{2}{*}{ 17-06-2021 } & 16.59 & Lembab & OFF & $\begin{array}{l}\text { Kelembaban tanah } 62 \% \\
\text { (basah), servo tetap tertutup } \\
\text { karena belum waktunya } \\
\text { penyiraman }\end{array}$ & Sesuai \\
\hline & 17.00 & Lembab & OFF & $\begin{array}{l}\text { Kelembaban tanah } 62 \% \\
\text { (basah), servo tetap tertutup } \\
\text { karena hujan dan kelembaban }\end{array}$ & Sesuai \\
\hline
\end{tabular}


$17.01 \quad$ Lembab

18-06-2021 $06.59 \quad$ Kering

$07.00 \quad$ Kering

18-06-2021 $16.59 \quad$ Kering

$17.00 \quad$ Kering

17.01 Lembab

19-06-2021

07.00

Kering

19-06-2021

Kering

OFF

OFF

OFF

masih sesuai

Kelembaban tanah 62\%

Sesuai

(basah), servo tetap tertutup

karena kelembaban masih

sesuai

OFF Kelembaban tanah 36\%

(kering), servo tetap tertutup

karena belum waktunya

penyiraman

$\mathrm{ON}$

Kelembaban tanah $36 \%$

(kering), servo akan terbuka

karena sudah waktunya

penyiraman

OFF Kelembaban tanah 64\%

(basah), servo menutup

karena kelembaban sudah

sesuai

OFF Kelembaban tanah 32\%

(kering), servo tetap tertutup

karena belum waktunya

penyiraman

ON Kelembaban tanah $32 \%$

(kering), servo akan terbuka

karena sudah waktunya

penyiraman

Kelembaban tanah 69\%

(basah), servo menutup

karena kelembaban sudah

sesuai

Kelembaban tanah 39\%

(kering), servo tetap tertutup

karena belum waktunya

penyiraman

ON Kelembaban tanah 39\%

(kering), servo akan terbuka

karena sudah waktunya

penyiraman

OFF Kelembaban tanah $71 \%$

(basah), servo menutup

karena kelembaban sudah

sesuai

$\mathrm{OFF}$

Kelembaban tanah 36\%

(kering), servo tetap tertutup

karena belum waktunya

penyiraman

$17.00 \quad$ Kering

ON

Kelembaban tanah 36\%

Sesuai

(kering), servo akan terbuka

karena sudah waktunya

penyiraman

$17.01 \quad$ Lembab

OFF Kelembaban tanah $67 \%$

Sesuai 
Setelah pengujian data dalam waktu lima hari yang terdapat dalam tabel 3 tersebut, dapat disimpulkan bahwa pengujian tersebut sudah sesuai dengan yang diharapkan. Dan pada tanggal 16 dan 17 jam 17.00 motor servo tidak terbuka dikarenakan hujan dan presentase kelembaban tanah masih menunjukan angka di atas $60 \%$.

\section{KESIMPULAN}

Berdasarkan pengujian pada penyiraman otomatis tanaman hias dapat disimpulkan bahwa Penyiraman otomatis pada tanaman hias ini dapat memudahkan pengguna saat menyiram tanaman hiasnya dengan jadwal yang dapat disesuaikan oleh pengguna dengan mengatur waktu penyiraman dan kelembaban yang sesuai pada tanaman hias tersebut.

Hasil dari pengujian penyiraman tanaman hias didapatkan nilai kelembaban setelah disiram $73 \%$ dan sebelum disiram 32\%. Implementasi berbasis mikrokontroler ke dalam penyiraman tanaman otomatis adalah jika sensor kelembaban tanah $>40 \%$ (kering) maka indikator lampur akan menyala dan membuka saluran air dengan putaran $180^{\circ}$ oleh motor servo. Namun, apabila sensor kelembaban tanah $>60 \%$ (basah) maka indikator lampu akan mati dan membalikkan motor servo ke sudut awal yaitu $0^{\circ}$ untuk menutup saluran air.

\section{DAFTAR PUSTAKA}

[1] M. Fadhil, B. D. Argo, and Y. Hendrawan, "Rancang Bangun Prototype Alat Penyiram Otomatis dengan Sistem Timer RTC DS1307 Berbasis Mikrokontroler Atmegal6 pada Tanaman Aeroponik Architecture of Prototype Automatic Sprinklers with a RTC DS1307 Timer System Based on Atmegal6 Microcontroller in Aerop," J. Keteknikan Pertan. Trop. dan Biosist., vol. 3, no. 1, pp. 37-43, 2015.

[2] E. Z. Kafiar, K. E. Allo, and D. J. Mamahit, 2018. "Rancang Bangun Penyiram Tanaman Berbasis Arduino Uno Menggunakan Sensor,” Vol. 7, No. 3,

[3] P. Ariyanto, A. Iskandar, and U. Darusalam, 2021, "Rancang Bangun Internet of Things (IoT) Pengaturan Kelembaban Tanah untuk Tanaman Berbasis Mikrokontroler," J. JTIK (Jurnal Teknol. Inf. dan Komunikasi), vol. 5, no. 2, p. 112, doi: 10.35870/jtik.v5i2.211.

[4] Z. Azhar, Fathurrahman, and Z. M. Nata, 2020. "Sistem Penyiraman Otomatis Berbasis Mikrokontroler Atmega328 Pada Tanaman Jambu Madu Deli Hijau," J. Ilmu Fis. dan Teknol., Vol. 4, No. 2, pp. 1-13,

[5] Nana Maliza, Z. Saifurrohman, and (Program Studi Elektro Sekalah Tinggi Teknik Multimedia Cendikia Abditama), 2017 "Alat Penyiraman Otomstis Berbasis Arduino Uno,” Jurnal Multimedia, Vol. 8, No. 1..

[6] A. Armanto, 2019, "Rancang Bangun Penyiram Tanaman Otomatis Menggunakan Sesor Kelembaban Tanah Berbasis Arduino," J. Teknol. Inf. Mura, Vol. 11, No. 02, pp. 76-83, doi: 10.32767/jti.v11i02.626. 
[7] G. sari Merliana, 2018, “Rancang Bangun Alat Penyiram Tanaman Otomatis Menggunakan Sensor Kelembaban Tanah,” J. Electr. Technol., Vol. 3, No. 1, pp. 13-17,

[8] C. Khairunisa, D. Triyanto, and I. Nirmala, 2018. "Implementasi Sistem Pengendalian Pemupukan dan Penyiraman Tanaman Otomatis Berbasis Arduino Mega 2560 Dengan Antarmuka Website,” J. Coding, Rekayasa Sist. Komput., Vol. 06, No. 03, pp. 87-96,

[9] W. Jatmiko, "Sistem Penyiram Tanaman Otomatis Berbasis Mikrokontroler dan Panel Surya,” pp. 199-203.

[10] R. B. Agung, M. Nur, and D. Sukayadi, 2019, “Menggunakan Sensor Kelembaban Tanah Berbasis Micro Contoller Atmega 328,” Cerita, Vol. 5, No. 1, pp. 97-106.

[11] J. J. Karwande and P. J. Karwande, 2020, “Automatic Watering System With Efficient Sun Tracking Solar Plate,” 2020 IEEE Int. Conf. Comput. Power Commun. Technol. GUCON 2020, pp. 794-797, doi: 10.1109/GUCON48875.2020.9231180.

[12] S. Bhardwaj, S. Dhir, and M. Hooda, 2018, “Automatic Plant Watering System Using Iot,” Proc. 2nd Int. Conf. Green Comput. Internet Things, ICGCIoT 2018, pp. 659-663, doi: 10.1109/ICGCIoT.2018.8753100.

[13] R. Tullah, Sutarman, and A. H. Setyawan, 2019, "Sistem Penyiraman Tanaman Otomatis Berbasis Mikrokontroler Arduino Uno pada Toko Tanaman Hias Yopi,” J. Sisfotek Glob., Vol. 9, No. 1, pp. 100-105.

[14] M. Mayuree, P. Aishwarya, and A. Bagubali, 2019, “Automatic Plant Watering System," Proc. - Int. Conf. Vis. Towar. Emerg. Trends Commun. Networking, ViTECoN 2019, pp. 1-3, doi: 10.1109/ViTECoN.2019.8899452. 